\title{
The butterflies of El Questro Wilderness Park, with remarks on the taxonomy of the Kimberley fauna, Australia
}

\author{
Michael F. Braby
}

\begin{abstract}
Biodiversity Conservation, Department of Land Resource Management, PO Box 496, Palmerston, Northern Territory 0831, Australia; and Research School of Biology, The Australian National University, Canberra, Australian Capital Territory 0200, Australia. Email: michael.braby@nt.gov.au
\end{abstract}

\begin{abstract}
El Questro Wilderness Park comprises a relatively large privately owned wilderness area in the monsoon tropics of the eastern Kimberley, north-western Australia. Targeted surveys for butterflies were conducted between 2009 and 2012 during the dry season. Fifty-three species were recorded; a further two species are recorded in the literature, bringing the total list of butterflies for El Questro Wilderness Park to 55 species (or $68 \%$ of the Kimberley fauna). Comments are made on their occurrence, relative abundance, habitat preference and larval food plant associations. Several species represent new records for the eastern Kimberley, most of which comprise significant range extensions from previously known coastal localities in the northern and/or western Kimberley. Taxonomic remarks are made for five species listed for the wider Kimberley region for which there is considerable uncertainty. One of these, Telicota ancilla baudina Evans, 1949, is shown to comprise a junior synonym of Telicota augias krefftii (W.J. Macleay, 1866); the others comprise taxonomic misidentifications (Pelopidas agna, Theclinesthes serpentatus) or there is doubt regarding their authenticity (Delias mysis, Danaus plexippus). The exclusion of these taxa brings the revised total number of species of butterflies recorded for the Kimberley to 81, of which only one is endemic to the region.
\end{abstract}

KEYWORDS: Australian Monsoon Tropics, butterfly biodiversity, Lepidoptera, nomenclature, Papilionoidea

\section{INTRODUCTION}

The Kimberley encompasses an immense wilderness area of north-western Australia (approximately 260,000 $\mathrm{km}^{2}$ ) and comprises one of four major subregions within the monsoon tropics of northern Australia (Woinarski et al. 2007; Bowman et al. 2010). The butterfly fauna of the Kimberley was recently reviewed by Braby (2008) who listed 85 species for this vast area, of which one (Nesolycaena caesia) is endemic to the region. Another species (Leptosia nina) is, within Australian limits, restricted to the Kimberley, but it also occurs widely in the Oriental Region. Apart from these two noteworthy components, available information suggests that despite the size of the region the butterfly fauna of the Kimberley is otherwise impoverished, with a relatively low species richness and low endemism, compared with the 'Top End' and Cape York Peninsula, two other major subregions of the Australian monsoon tropics (Braby 2008).

To date, most recording effort for butterflies in the Kimberley has been concentrated in the western (Warham 1957; Koch and van Ingen 1969; Common 1981; McKenzie et al. 1995; Grund 1998; Williams et al. 2006; Peters 2006, 2008; Pierce 2008, 2010) and northern (Bailey and Richards 1975; Yeates
1990; d'Apice and Miller 1992; Johnson 1993; Grund and Hunt 2001; Williams et al. 2006; Pierce 2008, 2010) parts of the region. In contrast, the fauna of the eastern Kimberley, although reasonably well documented, has been less intensively sampled in terms of its geographical coverage, with most attention focused around the Kununurra district (Koch 1957; Le Souëf 1971; Dunn 1980; Field 1990; Yeates 1990; Johnson 1993; Meyer 1995, 1996a; Grund and Hunt 2001; Franklin et al. 2005; Williams et al. 2006; Pierce 2010).

El Questro Wilderness Park (Figure 1), hereafter abbreviated to ElQ, comprises a relatively large privately owned wilderness area that lies in the heart of the eastern Kimberley. Perusal of the scientific literature indicates that it has been inadequately sampled, with only 13 species of butterflies recorded (Badamia exclamationis, Suniana lascivia, Telicota colon, Cephrenes trichopepla, Danaus petilia, Melanitis leda, Hypocysta adiante, Candalides erinus, Nesolycaena caesia, Nacaduba biocellata, Catopyrops florinda, Theclinesthes miskini and Lampides boeticus) (see Meyer 1996b; Grund 1998; Franklin et al. 2005; Williams et al. 2006; Braby 2011). In this report, I provide a detailed list of the butterflies of EIQ based on opportunistic and quantitative surveys between 2009 and 2012. The list is presented in annotated form 


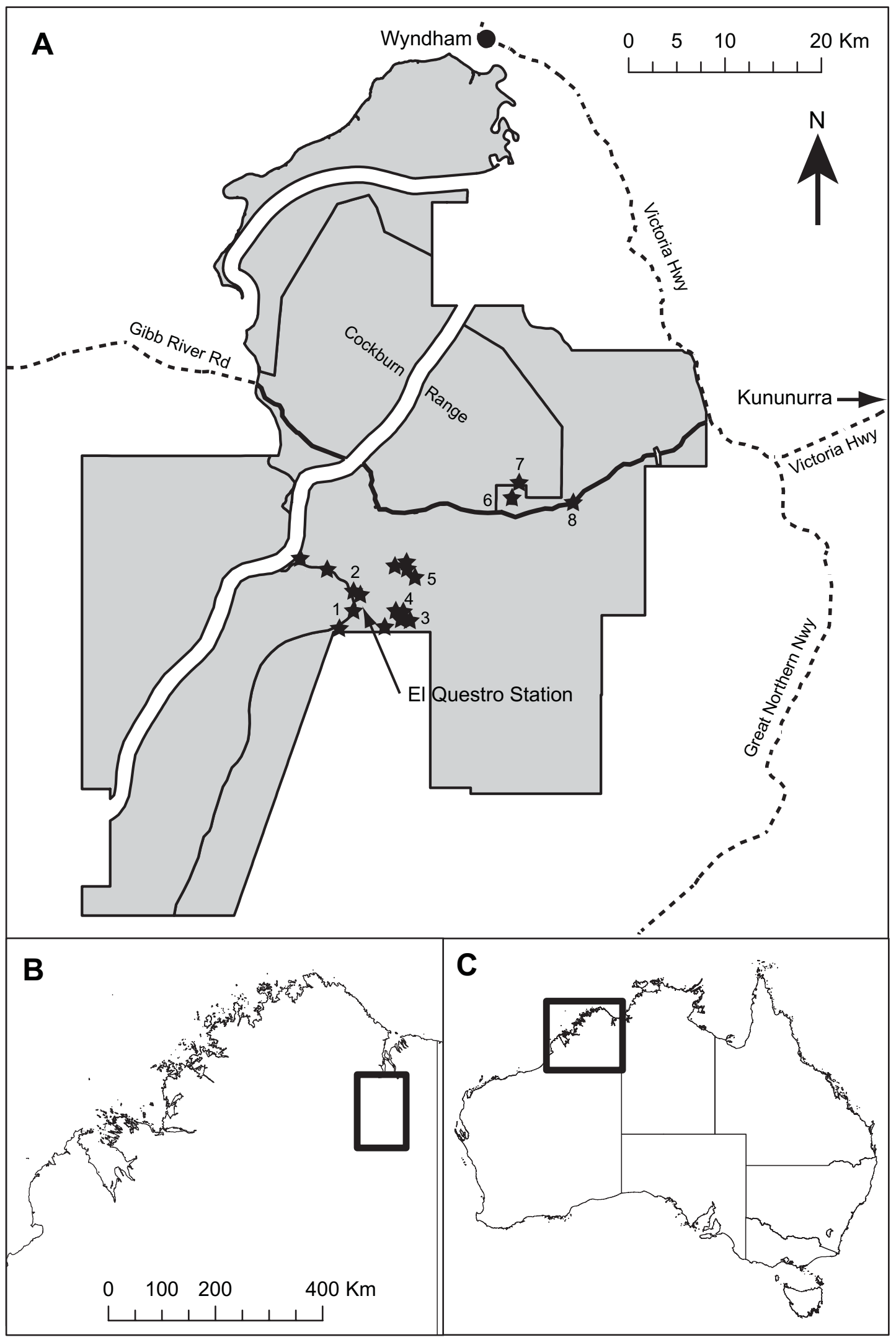

FIGURE 1 A. Map of study area showing El Questro Wilderness Park (shaded grey); B. map of the Kimberley, with extent rectangle showing EIQ in the eastern Kimberley; C. map of Australia, with extent rectangle showing the Kimberley in north-western Australia. Sampling sites are indicated by a star, with major sites indicated with numbers ( 1 = Pentecost River crossing (El Questro Rd), 2 = Saddleback Ridge, 3 = El Questro Gorge, 4 = Zebedee Springs, 5 = Amalia Gorge, 6 = Emma Gorge resort, $7=$ Emma Gorge plunge pool, $8=$ King River crossing). 


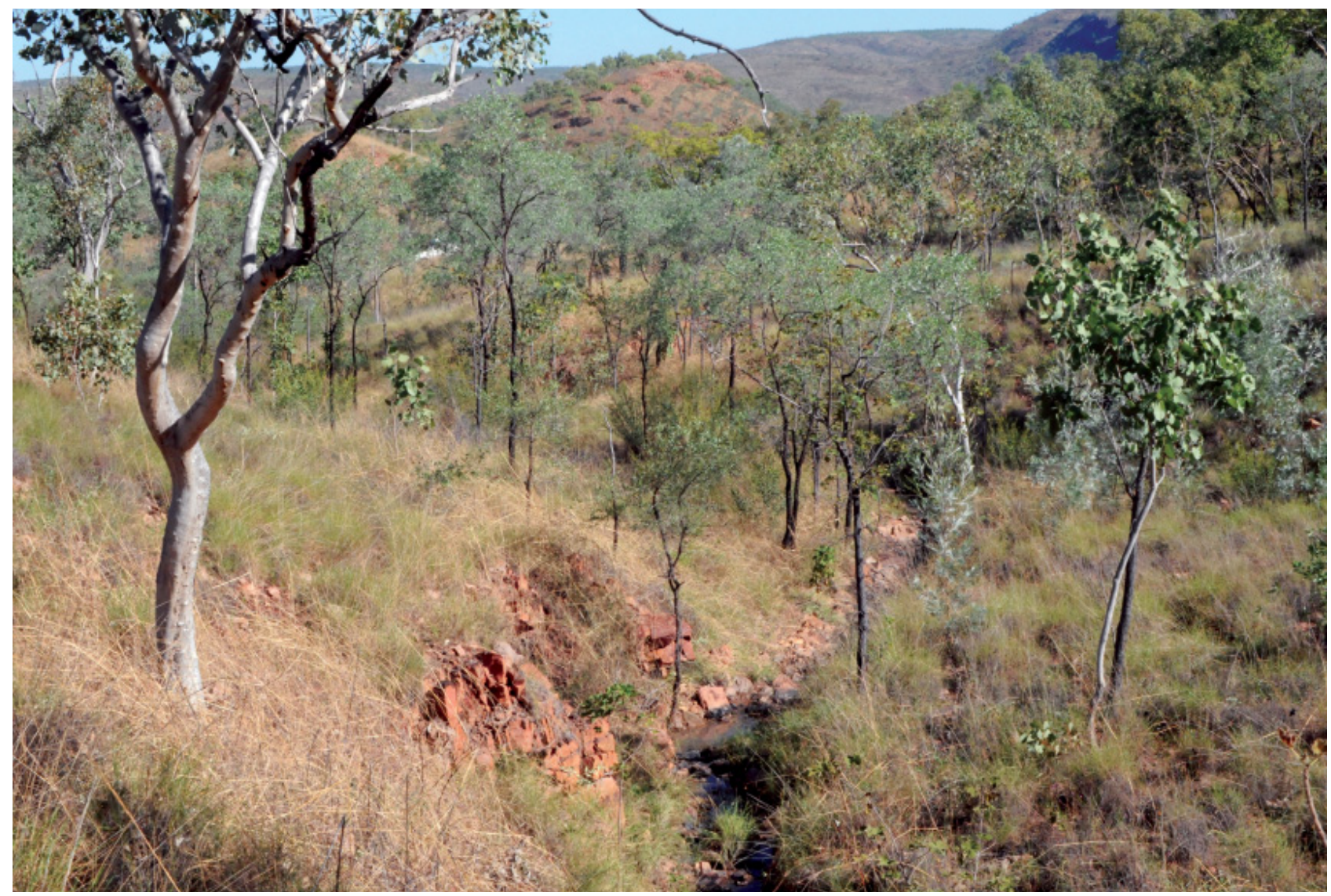

FIGURE 2 Savannah woodland along a dry gully, near Saddleback Ridge.

and includes information on occurrence, relative abundance, habitat preference and larval food plant associations, together with previously published records. The fauna is then placed in the context of what is known about the butterflies of the wider Kimberley region. Taxonomic remarks and comments are also made on five species from the region which have proven to be erroneous - these records are excluded from the Kimberley.

\section{STUDY AREA}

ElQ is located $50 \mathrm{~km}$ west of Kununurra and to the south of Wyndham (Figure 1). It comprises a vast wilderness area of approximately $2,700 \mathrm{~km}^{2}$ of complex ancient sandstone ranges and escarpments frequently dissected by steep-sided gorges. The vegetation is predominantly tropical savannah woodland with a spinifex understorey (Figure 2), but patches of monsoon forest persist along gorges with permanent springs (Figures 3, 4). Riparian paperbark open-forest with monsoon forest elements in the understorey also occurs along the banks of rivers such as the Pentecost River (Figure 5). ElQ lies in the lower rainfall (semi-arid) areas of the monsoon tropics in which the climate is monsoonal. The mean annual rainfall for Kununurra is approximately $800 \mathrm{~mm}$, with most of the rain falling during the wet season between November and March. January and February are the wettest months. Little rain falls during the dry season, which extends from April to
October. The driest period is from May to September. Mean maximum temperatures for Kununurra vary from $30^{\circ} \mathrm{C}$ in July to $39^{\circ} \mathrm{C}$ in November (when humidity is also high), and mean minimum temperatures range from $15^{\circ} \mathrm{C}$ in July to $26^{\circ} \mathrm{C}$ in December (Bureau of Meteorology 2012).

\section{METHODS}

Butterflies were identified and recorded using a combination of methods, including direct sampling, visual observation aided by the use of $10 \times 26$ field binoculars, and digital macro photography. Samples were collected using conventional entomological sweep nets, the specimens of which are currently lodged in the Museum and Art Gallery of the Northern Territory, Darwin, the Western Australian Museum, Perth, and the Australian National Insect Collection, Canberra. ElQ was visited on five occasions during the early and mid dry season: 14-18 July 2009, 3-5 April 2010, 15 May-3 June 2011, 2-6 August 2011 and 7-9 April 2012. Figure 1 shows the sites sampled, most of which are located close to the El Questro Station. Nearly all walking tracks and roads accessible to the public were visited, with many of the records made opportunistically (i.e. as incidental records); however, during May-June 2011 an intensive three-week quantitative inventory was conducted with the aid of volunteers across eight sampling sites, each comprising standardised $40 \mathrm{~m} \mathrm{x}$ $400 \mathrm{~m}$ transects that were sampled twice over a $3 \mathrm{~h}$ 

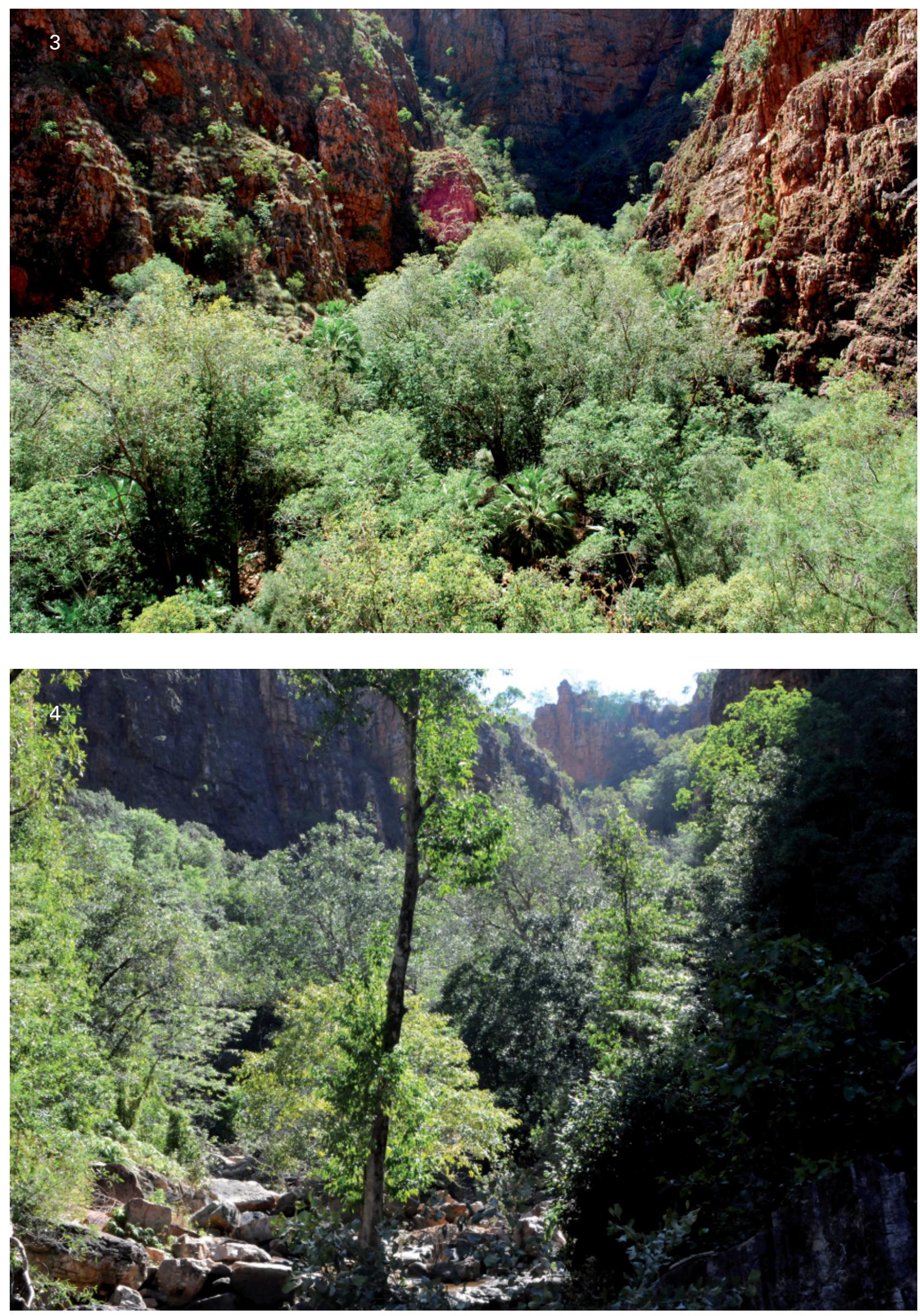

FIGURES 3-4 Monsoon forest along permanent springs: 3, El Questro Gorge; 4, Emma Gorge. 


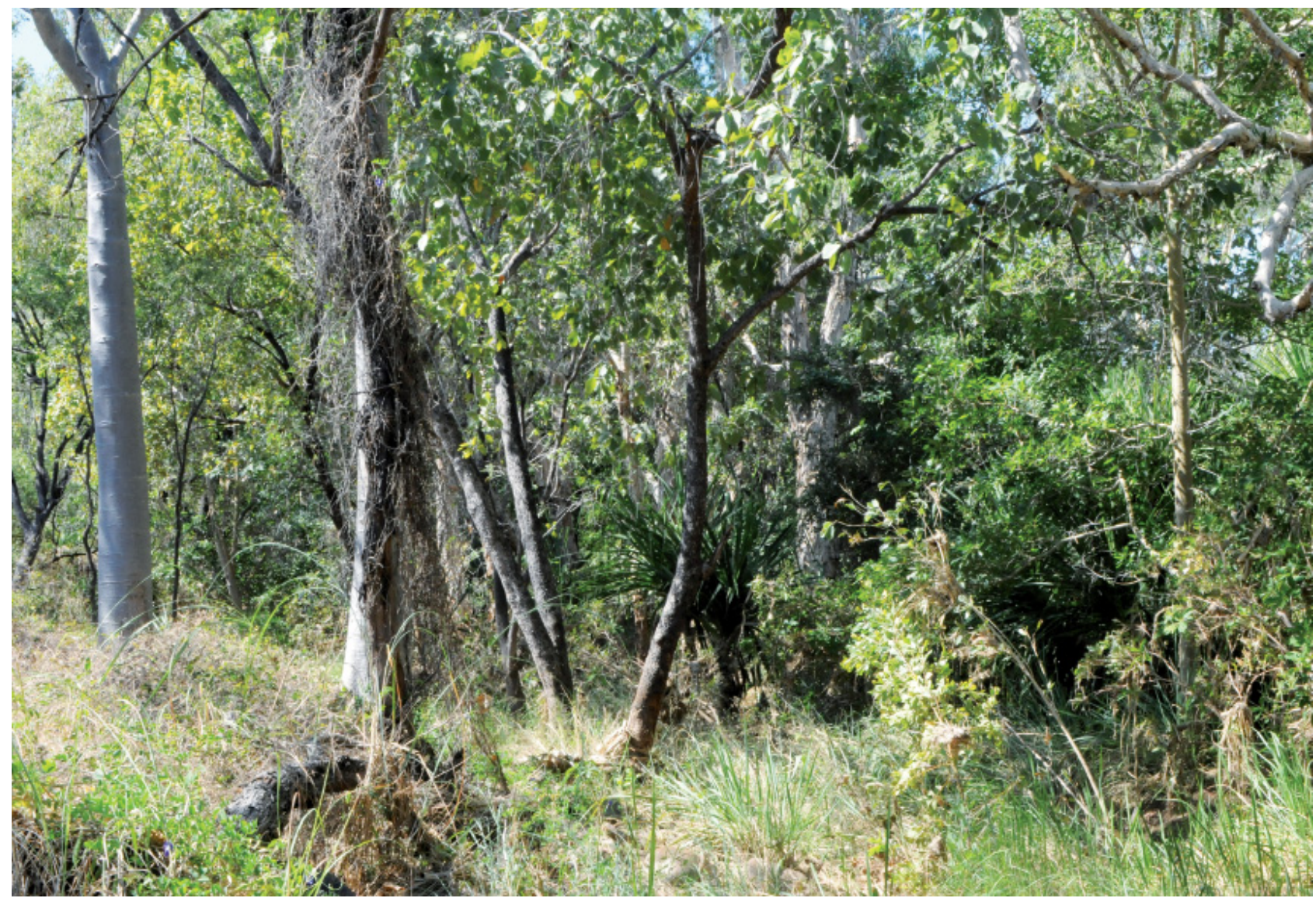

FIGURE 5 Riparian paperbark open-forest with rainforest elements in the understorey, Pentecost River.

period. Four of these sites were located in riparian areas along gorges/rivers with permanent (flowing) water and patches of monsoon forest; the four others were located in savannah woodland along seasonal gullies/ creeks that had no flowing water during the dry season. The numerical data for this survey will be reported elsewhere (M.F. Braby and M.R. Williams, unpublished data). Nomenclature for butterflies follows Braby (2010).

The following acronyms refer to repositories where specimens have been lodged and/or examined:

AM: $\quad$ Australian Museum, Sydney

ANIC: Australian National Insect Collection, Canberra

BMNH: Natural History Museum, London

NTM: Museum and Art Gallery of the Northern Territory, Darwin

WADA: Western Australia Department of Agriculture collection, Perth

WAM: Western Australian Museum, Perth

\section{RESULTS}

\section{HESPERIIDAE}

Badamia exclamationis (Fabricius, 1775), Narrowwinged Awl. Williams et al. (2006) recorded this species at Zebedee Springs in March 2003.

Proeidosa polysema (Lower, 1908), Spinifex Sandskipper. The early stages of this species were recorded at Saddleback Ridge and at a site $1 \mathrm{~km} \mathrm{~N}$ of Zebedee Creek crossing during May 2011. Larvae were found inside tubular shelters on tussocks of Triodia bitextura Lazarides (Poaceae) growing in savannah woodland on the lower slopes of a hill and along a dry rocky gully.

Pelopidas lyelli lyelli (Rothschild, 1915), Lyell's Swift. This species was generally recorded in moderate numbers ( $\geq 10$ adults) in riparian woodland with patches of monsoon forest along creeks with permanent water, and savannah woodland along dry rocky gullies; however, during the three-week survey in May-June 2011, adults were more frequently recorded and abundant in the wetter habitats. Larvae were commonly found in large tubular shelters on Mnesithea rottboellioides (R.Br.) de Koning and Sosef (Poaceae), a tall grass with broad blades, at Emma Gorge, Zebedee Springs and the Pentecost River crossing (El Questro Rd) near El Questro Station. Males established and defended territories by perching on low objects in sunlit areas during mid morning.

Taractrocera anisomorpha (Lower, 1911), Large Yellow Grass-dart. A single male was collected in a sunlit grassy area near the entrance of El Questro Gorge 
on 3 April 2010. An unidentified Taractrocera larva, possibly this species, was collected from within a shelter of dry grass leaves at Champaign Springs in August 2011, but the adult failed to emerge.

Ocybadistes hypomeloma vaga (Waterhouse, 1932), White-margined Grass-dart. Two males of this species were collected: one at Amalia Gorge on 15 July 2009, and another at El Questro Gorge on 3 April 2010. Both specimens were collected in moist sunlit grassy areas with permanent water near the entrances of the gorges.

Ocybadistes flavovittatus vesta (Waterhouse, 1932), Narrow-brand Grass-dart. Two males were collected, and others observed, on the campground lawns adjacent to the Pentecost River at El Questro Station on 9 April 2012.

Suniana lascivia larrakia L.E. Couchman, 1951, Dark Grass-dart. Braby (2011) recorded this species at El Questro Gorge where he observed a female during late morning deposit an egg on a broad fresh blade of Ischaemum australe R.Br. (Poaceae), which grew as a dense understorey grass along the edge of a creek, on 14 July 2009. Adults were also recorded at Amalia Gorge in July 2009 and at Emma Gorge Resort in April 2010. During May-June 2011, adults were recorded frequently, but in low numbers (1-2 adults) in the wetter habitats with permanent water (e.g. at Emma Gorge, Zebedee Springs, El Questro Gorge, and the Pentecost River crossing near El Questro Station). They usually occurred where the larval food plant grew in abundance in sunlit areas. The hind wing underside of these specimens is variable, but the material appears to be closest to the subspecies S. lascivia larrakia from the Top End.

Telicota colon argea (Fabricius, 1775), Pale-orange Darter. Braby (2011) recorded this species at Amalia Gorge where females were observed during the mid afternoon ovipositing on Ischaemum australe (Poaceae) growing along a creek on 15 July 2009; a larva was also collected within its shelter on the larval food plant and reared to adult in captivity. A female was collected from El Questro Gorge on 3 April 2010. During MayJune 2011, the species was recorded only in the wetter habitats (e.g. at Emma Gorge, Zebedee Springs, and the Pentecost River crossing near El Questro Station) where larvae were found inside tubular shelters of Mnesithea rottboellioides (Poaceae) growing as a tall grass along the banks of streams; three larvae were reared to adult in captivity.

Cephrenes trichopepla (Lower, 1908), Yellow Palmdart. Williams et al. (2006) recorded this species at Zebedee Springs in March 2003, and Braby (2011) found it at both El Questro Gorge and the Pentecost River (4 km NW of El Questro Station) breeding on Livistona nasmophila Dowe and D.L. Jones (Arecaceae) in July 2009 and April 2010, respectively. Adults were also recorded at Amalia Gorge in July 2009. During MayJune 2011, adults and larvae were found frequently, but in low numbers $(<10)$, in riparian monsoon forest along El Questro Gorge and Zebedee Springs, and in riparian paperbark open-forest with monsoon forest elements in the understorey along the bank of the Pentecost River crossing (El Questro Rd) near El Questro Station. At these sites, larvae were usually found on L. nasmophila, but on the Pentecost River they were also recorded on L. lorophylla Becc. (Arecaceae) growing in the ecotone between riparian forest and savannah woodland. The material collected has the underside ground colour of the hind wing conspicuously suffused with green (particularly evident in reared specimens).

\section{PAPILIONIDAE}

Graphium eurypylus nyctimus (Waterhouse and Lyell, 1914), Pale Triangle. A single adult was recorded in riparian monsoon forest at Emma Gorge plunge pool on 4 April 2010.

Papilio demoleus sthenelus W.S. Macleay, 1826, Chequered Swallowtail. This species was recorded near the entrances of Amalia Gorge and El Questro Gorge in April 2010. During May-June 2011, it was recorded infrequently and in low numbers (1-2) in savannah woodland (e.g. at a site $1 \mathrm{~km} \mathrm{~N}$ of Zebedee Creek crossing, and near El Questro Station); males were also recorded hilltopping (a mate location behaviour in which males search for receptive females for mating) at the lookout on Saddleback Ridge.

\section{PIERIDAE}

Catopsilia pyranthe crokera (W.S. Macleay, 1826), White Migrant. This migratory species was recorded in the early dry season at several sites, including Emma Gorge, Amalia Gorge and El Questro Gorge half way pool in April 2010, and again at El Questro Station in April 2012; however, it was not observed during the mid dry season in May-June 2011.

Catopsilia pomona (Fabricius, 1775), Yellow Migrant. This species was recorded regularly, but in low numbers $(<10)$, throughout ElQ and in a wide range of habitats during May-June 2011.

Catopsilia scylla etesia (Hewitson, 1867), Orange Migrant. This species was recorded on two occasions: a female was collected at a site $1.2 \mathrm{~km} \mathrm{NW}$ of Amalia Creek crossing as it flew rapidly along a dry rocky sandstone gully on 30 May 2011, and a male was observed at El Questro Station on 6 August 2011.

Eurema laeta sana (Butler, 1877), Lined Grass-yellow. A single specimen (dry season form) was collected in riparian paperbark open-forest with monsoon forest elements in the understorey on the Pentecost River crossing (El Questro Rd) near El Questro Station on 1 June 2011.

Eurema herla (W.S. Macleay, 1826), Pink or Macleay's Grass-yellow. This species was recorded frequently, but usually in low numbers $(<10)$, in savannah woodland along dry rocky gullies during May-June 2011. A few specimens were also recorded at Emma Gorge, a wetter site with flowing water.

Eurema smilax (Donovan, 1805), Small Grass-yellow. This species was recorded in low numbers (1-2) usually along dry gullies, including sites at $1.5 \mathrm{~km} \mathrm{~N}$ of Amalia Creek crossing, $1 \mathrm{~km} \mathrm{~N}$ of Zebedee Creek crossing, and at the base of Saddleback Ridge; it was also recorded at 
El Questro Gorge and the Pentecost River crossing (El Questro Rd) near El Questro Station.

Eurema hecabe (Linnaeus, 1758), Large Grassyellow. This species was recorded in moderate numbers (10-50) throughout ElQ in a wide range of vegetation types, and it was equally abundant in both wet and dry habitats during May-June 2011. Eggs were found on the foliage of Breynia cernua (Poir.) Muell.Arg. (Phyllanthaceae) growing in monsoon forest in the wetter habitats at Zebedee Springs and Pentecost River crossing (El Questro Rd), but at El Questro Gorge a female was observed ovipositing on Phyllanthus sp. (Phyllanthaceae).

Elodina padusa (Hewitson, 1853), Narrow-winged Pearl-white. A few adults of this species were recorded in savannah woodland along a dry rocky sandstone gully with some monsoon forest elements at a site 1.2 km NW of Amalia Creek crossing during May 2011. A single specimen was also collected at Emma Gorge in riparian woodland with patches of monsoon forest on steep slopes above the bank on 26 May 2011.

Elodina walkeri Butler, 1898, Small Pearl-white. This species was recorded in low numbers $(<10)$ during April 2010 and May-June 2011, but it was more widespread and abundant than E. padusa. It was most often encountered in moister habitats with permanent water and patches of monsoon vine thicket, including the slopes of Emma and El Questro Gorges; at the latter site adults frequently alighted on tall shrubs of Capparis jacobsii Hewson (Capparaceae), a possible a larval food plant. On several occasions adults were also recorded in savannah woodland, although they may have been dispersing through, rather than breeding in, this habitat.

Belenois java teutonia (Fabricius, 1775), Caper White. No adults of this migratory species were observed; however, a single pupal exuvia was found on a shrub of Capparis jacobsii (Capparaceae) growing in savannah woodland along a dry rocky sandstone gully with some monsoon forest elements $1.2 \mathrm{~km} \mathrm{NW}$ of Amalia Creek crossing in May 2011.

Cepora perimale scyllara (W.S. Macleay, 1826), Caper Gull. This species was recorded in moderate numbers $(\geq 10)$ throughout ElQ in a wide range of vegetation types, and it was equally abundant in both wet and dry habitats during May-June 2011. Eggs were found on Capparis jacobsii (Capparaceae), which grew as a large shrub in vine thicket on steep rock scree slopes of El Questro Gorge; eggs and larvae were also recorded on both $C$. jacobsii and $C$. umbonata growing in savannah woodland along a dry rocky sandstone gully with some monsoon forest elements at a site 1.2 km NW of Amalia Creek crossing.

Delias argenthona fragalactea (Butler, 1869), Scarlet Jezebel. This species was recorded at Emma Creek in the Cockburn Ranges, Emma Gorge Resort, Amalia Gorge and King River crossing on the Gibb River Road. At Emma Gorge Resort, adults were observed during the morning flying around and feeding on the flowers of Corymbia sp. growing at the car park during 24-25 May and 4 August 2011. A cohort of 10 first instar larvae and three prepupae were subsequently recorded on the mistletoe Dendrophthoe glabrescens (Blakely) Barlow (Loranthaceae) growing in the canopy of Erythrophleum chlorostachys (F.Muell.) Baill. at this site on 2 June 2011; a live pupa and one dead pupa were also found on grass blades about $1 \mathrm{~m}$ from ground level not far from the host tree. The larvae were collected and two adults were reared in captivity. The site was revisited on 4 August 2011 and a cohort of 14 final instar larvae was observed on the same clump of Dendrophthoe glabrescens. An adult and a cohort of five final instar larvae were recorded on a clump of Amyema sanguinea (F.Muell.) Danser (Loranthaceae) parasitising Eucalyptus camaldulensis Dehnh. growing in riparian woodland at King River crossing on 2-3 August 2011.

\section{NYMPHALIDAE}

Libythea geoffroy genia Waterhouse, 1938, Purple Beak. This species was recorded only at Emma and El Questro Gorges. At Emma Gorge plunge pool, a male in worn condition was photographed basking after drinking from moist sand during mid morning on 17 July 2009. At El Questro Gorge half way pool, a male in good condition was collected whilst settled on rocks/moist sand along the gorge on 3 April 2010. At both sites the putative larval food plant, Celtis philippensis Blanco (Cannabaceae), grew in abundance in monsoon forest on the steep sandstone slopes above creeks with permanent water.

Danaus petilia (Stoll, 1790), Lesser Wanderer. Braby (2011) recorded this species at Emma Gorge breeding (i.e. eggs and larvae) on Tylophora flexuosa R.Br. (Apocynaceae) growing on sandstone rock scree just above Emma Creek in July 2009. During May-June 2011, the species was recorded in moderate numbers (10-50) throughout ElQ in a wide range of habitats; however, it was more abundant in the wetter habitats with permanent water, for example, at El Questro Gorge.

Danaus affinis affinis (Fabricius, 1775), Swamp Tiger. A few adults were recorded in riparian paperbark openforest with monsoon forest elements in the understorey on the Pentecost River crossing (El Questro Rd) near El Questro Station during May-June 2011.

Euploea corinna (W.S. Macleay, 1826), Common Crow. This was the commonest species at ElQ, being recorded in high numbers in a wide range of habitats. It was most abundant in the wetter habitats (e.g. at El Questro Gorge, and Emma Gorge) where immense overwintering aggregations ( $>1000$ individuals) were observed during the dry season in May-June 2011. Eggs and larvae were found on Gymnanthera oblonga (Burm.f.) P.S.Green and Tylophora sp. (Apocynaceae) growing in riparian paperbark openforest with monsoon forest elements in the understorey at the Pentecost River crossing (El Questro Rd) near El Questro Station. A mid instar larva was also recorded feeding on Sarcostemma viminale (L.) R.Br. (Apocynaceae) growing on open sandstone pavement at Champaign Springs in April 2012.

Acraea andromacha andromacha (Fabricius, 1775), Glasswing. This species was recorded throughout ElQ in a wide range of habitats, but usually in low numbers 
(1-2). It was more abundant at Emma and El Questro Gorges where larvae were found feeding on Adenia heterophylla (Blume) Koord. (Passifloraceae) growing in riparian monsoon forest.

Junonia orithya albicincta Butler, 1875, Blue Argus. This species was recorded in moderate numbers $(\geq 10)$ throughout ElQ in a wide range of vegetation types, and it was equally abundant in both wet and dry habitats during May-June 2011. A larva and a pupa were found on Buchnera asperata R.Br. (Orobanchaceae) growing in savannah woodland along a dry gully at the base of Saddleback Ridge in May 2011.

Junonia villida villida (Fabricius, 1787), Meadow Argus. This species was recorded in low numbers (1-2) throughout ElQ, although it was more frequently encountered in the drier habitats comprising savannah woodland.

Junonia hedonia zelima (Fabricius, 1775), Chocolate Argus. This species was recorded on two occasions: a single specimen was collected in riparian woodland with patches of monsoon forest at Emma Gorge on 2 June 2011, and another was observed in riparian swampland on the Pentecost River approximately 2.5 km S of El Questro Station on 8 April 2012.

Hypolimnas bolina nerina (Fabricius, 1775), Varied Eggfly. This species was recorded on the Pentecost River $4 \mathrm{~km} \mathrm{NW}$ of El Questro Station in April 2010. During May-June 2011, it was recorded in low numbers (1-2) and only in the wetter habitats comprising monsoon forest with permanent water (e.g. Emma Gorge, Zebedee Springs, El Questro Gorge, Moonshine Gorge, and the Pentecost River near El Questro Station).

Charaxes sempronius sempronius (Fabricius, 1793), Tailed Emperor. This species was recorded from many sites throughout ElQ during May and August 2011, but in low numbers (1-2). It was usually observed in savannah woodland or riparian woodland, but occasionally in monsoon forest (e.g. at Emma Gorge, and El Questro Gorge). Males were recorded hilltopping at the lookout on Saddleback Ridge.

Melanitis leda bankia (Fabricius, 1775), Evening Brown. Franklin et al. (2005) recorded this species at Amalia Gorge on 14 August 2004. A few adults were recorded at Zebedee Springs and the Pentecost River crossing (El Questro Rd) near El Questro Station during May-June 2011 and April 2012. They were usually flushed from deep shade within riparian monsoon forest dominated by Livistona nasmophila or riparian paperbark open-forest with monsoon forest elements in the understorey. A pupa was collected on the underside of a leaf of Barringtonia acutangula (L.) Gaertn. from the Pentecost River; it subsequently proved to be parasitised by a species of Diptera. The larval food plant at this site was not determined, but it was possibly Imperata cylindrica (L.) Reausch. (Poaceae), which was locally abundant in the area.

Hypocysta adiante antirius Butler, 1868, Orange Ringlet. Franklin et al. (2005) and Williams et al. (2006) both recorded this species, at El Questro Station in August 2004, and Amalia Gorge and Zebedee Springs in
March-April 2003, respectively. Braby (2011) recorded it at El Questro Gorge, where he noted a late instar larva feeding on a blade of Ischaemum australe (Poaceae) on 14 July 2009. During May-June 2011, the species was recorded in high numbers (10-100) throughout ElQ in a wide range of vegetation types, and it was equally abundant in both wet and dry habitats.

Ypthima arctous arctous (Fabricius, 1775), Dusky Knight. This species was recorded in low numbers $(<10)$, usually in savannah woodland along dry creeks and gullies or in riparian woodland, but it was also recorded along the edge of wet monsoon forest at Zebedee Springs.

\section{LYCAENIDAE}

Arhopala eupolis asopus Waterhouse and Lyell, 1914, Purple Oak-blue. This species was recorded only at El Questro Gorge and the Pentecost River at El Questro Station, where it was restricted to riparian monsoon forest or riparian paperbark open-forest with monsoon forest elements in the understorey and colonies of the attendant ant Oecophylla smaragdina. At both of these locations it was reasonably abundant, being observed in moderate numbers $(>10)$ during the afternoon.

Ogyris amaryllis (Hewitson, 1862), Satin Azure. A breeding colony of this species was recorded at King River crossing on the Gibb River Road on 2-3 August 2011. Numerous eggs were found singly on the junctions of stems of Amyema sanguinea (Loranthaceae) parasitising Eucalyptus camaldulensis growing in riparian woodland; an early instar larva and a pupa (both of which were reared to adult in captivity) were also collected under loose bark of branches of the host tree around which the mistletoe grew. Males flew high in the canopy of the host tree, frequently alighting for short periods on dead branches and clumps of the larval food plant during early to mid afternoon; a female was observed lower down flying around and settling on the foliage of the food plant, also during mid afternoon. The subspecific status of this population has not been determined.

Anthene lycaenoides godeffroyi (Semper, [1879]), Pale Ciliate-blue. This species was recorded on two occasions: a female was observed in monsoon vine thicket growing on a steep slope of El Questro Gorge on 17 May 2011, and a female was collected in riparian paperbark open-forest with monsoon forest elements in the understorey on the Pentecost River crossing (El Questro Rd) near El Questro Station on 21 May 2011.

Candalides margarita gilberti Waterhouse, 1903, Trident Pencil-blue. This species was recorded at Emma Gorge and King River crossing on the Gibb River Road. At Emma Gorge Resort, two empty egg shells were collected from the petiole of a leaf of Dendrophthoe glabrescens (Loranthaceae) parasitising Erythrophleum chlorostachys on 2 June 2011. Further upstream at Emma Gorge, a female was observed at $1245 \mathrm{~h}$ WST associated with a clump of Amyema bifurcata (Benth.) Tiegh. (Loranthaceae) parasitising Corymbia confertiflora (F.Muell.) K.D. Hill and L.A.S. Johnson on 4 August 2011; the butterfly flew around the mistletoe clump, which grew high up in the canopy, for several 
minutes during which time she frequently alighted on the foliage, sometimes to bask, but it could not be ascertained if she laid eggs. At King River crossing, several eggs were found on the foliage of Amyema sanguinea parasitising Eucalyptus camaldulensis growing in riparian woodland on 3 August 2011; one egg hatched two days later and the first instar larva was preserved.

Candalides erinus erinus (Fabricius, 1775), Small Dusky-blue. Braby (2011) recorded this species at Amalia Gorge, where a larva was collected on Cassytha capillaris Meisn. (Lauraceae) parasitising Triodia sp. growing on a lower rocky slope with a north facing aspect above the gorge on 2 April 2010. During MayJune 2011, the species was found to be widespread, but usually recorded in low numbers $(<10)$, often on open rocky slopes with spinifex adjacent to wetter habitats comprising monsoon forest. At the base of Saddleback Ridge, it was locally abundant in savannah woodland along a dry gully where females were observed ovipositing on $C$. capillaris parasitising Triodia bitextura. Males were also recorded hilltopping at the lookout on Saddleback Ridge during May 2011.

Candalides delospila (Waterhouse, 1903), Spotted Dusky-blue. A single male was collected in savannah woodland with a spinifex-dominated understorey on sandstone at Saddleback Ridge not far from the lookout on 16 May 2011.

Nesolycaena caesia d'Apice and Miller, 1992, Kimberley Opal. Meyer (1996b) recorded this species in a shallow gully on the El Questro Road $0.7 \mathrm{~km} \mathrm{~N}$ of Amalia Gorge in April 1995.

Nacaduba biocellata biocellata (C. and R. Felder, 1865), Two-spotted Line-blue. Franklin et al. (2005) recorded a few individuals of this species at El Questro Station in August 2008. During May-June 2011, the species was recorded mainly in savannah woodland but occasionally in riparian monsoon forest (e.g. at Emma Gorge, and El Questro Gorge). At the base of Saddleback Ridge, adults were locally abundant and larvae were collected (and reared to adult) on the flower buds of trees of Acacia plectocarpa A.Cunn. ex Benth. (Fabaceae). Males were particularly abundant at this site during mid morning, fluttering slowly close to the ground within a few metres of the base of tree trunks of the larval food plant; however, by early afternoon their flight behaviour changed dramatically and they were noted to fly in fewer numbers around flowers and leaves in the canopy of the food plant. The larvae of $N$. biocellata are known to pupate in the leaf litter and debris on the ground at the base of the food plant (Braby 2000) and presumably the pupation sites are used as encounter sites by males during the morning to detect freshly emerged (receptive) females for mating.

Prosotas dubiosa dubiosa (Semper, [1879]), Purple Line-blue. A single male was collected in savannah woodland along a dry gully at the base of Saddleback Ridge on 28 May 2011.

Catopyrops florinda estrella (Waterhouse and Lyell, 1914), Speckled Line-blue. Williams et al. (2006) recorded this species near Amalia Gorge based on the observations of C.E. Meyer. Braby (2011) subsequently found the species breeding (i.e. eggs and larva) on Dodonaea hispidula Endl. (Sapindaceae) near the entrance of Amalia Gorge on 2 April 2010. During May-June 2011, the species was regularly recorded in moderate numbers $(\geq 10)$ in the wetter habitats comprising monsoon forest with permanent water, but it was also frequently recorded in savannah woodland along dry gullies. Eggs and larvae were also recorded on D. hispidula at Emma Gorge and at a site $1.5 \mathrm{~km} \mathrm{~N}$ of Amalia Creek crossing.

Theclinesthes miskini miskini (T.P. Lucas, 1889), Wattle Blue. Braby (2011) recorded this species breeding (i.e. eggs, ovipositing female) on a sapling of Acacia holosericea A.Cunn. ex G.Don (Fabaceae) growing in riparian woodland along the bank of the Pentecost River 4 km NW of El Questro Station on 2 April 2010; the larval food plant was occupied by a colony of sugar ants Camponotus sp. denticulatus group, which may have been attending the early stages. During May-June 2011, T. miskini was recorded from many sites, mainly in savannah woodland, but generally in low numbers (1-2). It was more abundant at the lookout of Saddleback Ridge where males were observed hilltopping during the afternoon.

Jamides phaseli (Mathew, 1889), Purple Cerulean. This species was usually recorded in moderate numbers $(\geq 10)$ from several habitats, but mostly in riparian monsoon forest; however, it was very numerous $(\geq 100)$ at Emma Gorge in May 2011 and at El Questro Gorge in April 2012. Adults were locally abundant around shrubs of Bossiaea bossiaeoides (A.Cunn. ex Benth.) Court (Fabaceae) at Emma Creek on the plateau of the Cockburn Ranges; a female was subsequently observed in the afternoon ovipositing on new leaf growth of this plant growing in the understorey of riparian eucalypt woodland along a sandstone gully with a spinifex understorey. Further searches revealed a number of eggs, all laid singly on dried leaf tissue of this plant. Eggs were not found on the flower buds, which were numerous.

Catochrysops panormus platissa (Herrich-Schäffer, 1869), Pale Pea-blue. This species was recorded on two occasions: a male was collected in riparian paperbark open-forest with monsoon forest elements in the understorey on the Pentecost River crossing (El Questro Rd) near El Questro Station on 31 May 2011, and several adults (one male of which was collected) were recorded at the entrance to El Questro Gorge on 7 April 2012.

Lampides boeticus (Linnaeus, 1767), Long-tailed Pea-blue. Both Grund (1998) and Franklin et al. (2005) made references to this species. Grund (1998) recorded the immature stages on Crotalaria novae-hollandiae DC. (Fabaceae) at El Questro Gorge during October 1997, while Franklin et al. (2005) noted two individuals (one of which was netted) near the bank of the Pentecost River in August 2004. The species was recorded infrequently during this study: a male was collected in riparian woodland on the Pentecost River $4 \mathrm{~km} \mathrm{NW}$ of El Questro Station on 2 April 2010, and a female was 
collected in savannah woodland along a rocky sandstone gully $0.7 \mathrm{~km} \mathrm{~N}$ of Amalia Gorge on 14 May 2011.

Zizina otis labradus (Godart, [1824]), Common Grassblue. This species was frequently recorded in moderate numbers $(\geq 10)$ in savannah woodland, especially along dry rocky gullies, in many areas of ElQ during MayJune 2011.

Famegana alsulus alsulus (Herrich-Schäffer, 1869), Black-spotted Grass-blue. This species was recorded predominantly in savannah woodland along dry gullies where at some sites it was very abundant during MayJune 2011. A female was observed during the morning ovipositing on Vigna lanceolata Benth. var. filiformis (Fabaceae) at the base of Saddleback Ridge.

Zizula hylax attenuata (T.P. Lucas, 1890), Dainty Grass-blue. This species was recorded on two occasions: a specimen was collected on the edge of riparian paperbark-pandanus open-forest at the Pentecost River crossing (El Questro Rd) near El Questro Station on 21 May 2011, and another was collected on the edge of monsoon forest at El Questro Gorge on 27 May 2011.

Euchrysops cnejus cnidus Waterhouse and Lyell, 1914, Spotted Pea-blue. This species was recorded infrequently in ElQ and usually in low numbers $(<10)$ during May-June 2011. It was observed mainly in savannah woodland along dry rocky gullies, but it was also recorded in the ecotonal habitat along the Pentecost River near El Questro Station.

Freyeria putli putli (Kollar, [1844]), Jewelled Grassblue. This species was recorded very infrequently in both dry and wet habitats throughout ElQ during MayJune 2011, always as solitary individuals.

\section{DISCUSSION}

Fifty-five species of butterflies are now recorded for ElQ. This number represents two-thirds of all butterfly species listed for the entire Kimberley (Braby 2008). However, since no surveys have been undertaken during the wet season, additional species are to be expected. Comparison of the list with reports elsewhere in the eastern Kimberley, particularly the KununurraWyndham district, indicate that a further 10 species (Hesperilla sexguttata, Suniana sunias, Papilio fuscus, Danaus genutia, Tirumala hamata, Hypolimnas misippus, Ogyris oroetes, O. zosine, Theclinesthes sulpitius, Zizeeria karsandra) have been recorded, but not from ElQ (see compilations in Koch 1957; Le Souëf 1971; Dunn 1980, 1985; Field 1990; Meyer 1996a; Braby 2000, 2011; Grund and Hunt 2001; Williams et al. 2006). Some of these species may well occur in ElQ, especially from the northern sections such as the Cockburn Range, which remains poorly surveyed.

No new butterfly records for the Kimberley were detected during the survey, but several species are worthy of comment. Five species (Ocybadistes hypomeloma, Graphium eurypylus, Eurema laeta, Anthene lycaenoides, Jamides phaseli) represent new records for the eastern Kimberley, and most of these comprise significant range extensions from previously known coastal localities in the northern and/or western Kimberley. Meyer (1996b) collected a single female of Nesolycaena caesia near Amalia Gorge in April 1995; the butterfly otherwise is known only from the northern Kimberley near Kalumburu (d'Apice and Miller 1992) and represents the only species of butterfly endemic to the entire Kimberley. Extensive searches for this sedentary species, and its putative larval food plant Boronia wilsonii (F.Muell. ex Benth.) Duretto, failed to detect its presence. The specimen collected by Meyer was in good condition according to extent of wing wear, indicating that a breeding population of $N$. caesia occurs within or close to ElQ. It is possible that the species breeds on the upper sandstone slopes and lower escarpments of the Cockburn Range, $10 \mathrm{~km}$ to the north of Amalia Gorge, and that the captured female had dispersed out of the plateau country.

The extent of the study was too limited to determine the relative proportions of butterfly species that are resident, immigrant and vagrant. However, larval food plants were recorded for 24 species (44\%) of butterflies at ElQ (Table 1) and, with the exception of Belenois java, these butterflies are considered to be resident (i.e. breed regularly with some life cycle stage present throughout the year). In general, there was a distinction between species breeding in the wet or dry habitats according to their larval food plant associations, with apparently more species in the former; but at least four species (Cepora perimale, Euploea corinna, Candalides erinus, Catopyrops florinda) were found breeding on plants growing in both habitats. Out of a total of 33 butterfly-plant associations recorded for ElQ (Table 1), 10 represent new larval food plant associations for Australia, viz. Mnesithea rottboellioides for Telicota colon and Pelopidas lyelli, Triodia bitextura for Proeidosa polysema, Capparis jacobsii for Cepora perimale and Belenois java, Sarcostemma viminale for Euploea corinna, Buchnera asperata for Junonia orithya, Amyema sanguinea for Candalides margarita, Bossiaea bossiaeoides for Jamides phaseli, and Acacia plectocarpa for Nacaduba biocellata, while several others represent new associations for north-western Australia (cf. Braby 2000; 2011). A more detailed list of these new associations will be reported elsewhere.

\section{TAXONOMIC REMARKS ON THE KIMBERLEY FAUNA}

Braby (2008) listed 85 species of butterflies for the Kimberley; however, during the course of scrutinising the literature for this study it became apparent that records for four of these species, plus a fifth that was overlooked in that review, are in error. These records are excluded, bringing the revised total number of species for the Kimberley to 81. Justification and taxonomic remarks are provided below for the exclusion of these species from the fauna. In addition, it is worth mentioning the record of the papilionid Pachliopta liris (Godart, 1819) from the Kimberley. Rothschild (1895) dismissed this record, but Waterhouse and Lyell (1914, p. 169) formally listed and illustrated the species and stated that 'we believe that a form of this species does occur in northwest Australia, probably 
TABLE 1 Confirmed larval food plant associations for butterflies at El Questro Wilderness Park according to broad habitat type. Wet habitats comprise riparian woodland, often with patches of monsoon forest, along gorges/rivers with permanent (flowing) water; dry habitats comprise savannah woodland along seasonal gullies/creeks or rocky slopes that had no flowing water during the dry season.

\section{Butterfly species}

Larval food plant

\section{Arecaceae}

Livistona nasmophila

Livistona lorophylla

\section{Poaceae}

Undetermined grass sp.

Ischaemum australe

Mnesithea rottboellioides

Triodia bitextura

\section{Apocynaceae}

Gymnanthera oblonga

Sarcostemma viminale

Tylophora flexuosa

Tylophora $\mathrm{sp}$.

\section{Capparaceae}

Capparis jacobsii

Capparis umbonata

Fabaceae

Acacia holosericea

Acacia plectocarpa

Bossiaea bossiaeoides

Crotalaria novae-hollandiae

Vigna lanceolata

\section{Lauraceae}

Cassytha capillaris

\section{Loranthaceae}

Amyema sanguinea

Dendrophthoe glabrescens

\section{Orobanchaceae}

Buchnera asperata

\section{Passifloraceae}

Adenia heterophylla

\section{Phyllanthaceae}

Breynia cernua

Phyllanthus sp.

Sapindaceae

Dodonaea hispidula

\section{Cephrenes trichopepla}

Cephrenes trichopepla

\section{Melanitis leda}

Suniana lascivia, Telicota colon, Hypocysta adiante

Telicota colon, Pelopidas lyelli

Proeidosa polysema

Euploea corinna

Euploea corinna

Danaus petilia

Euploea corinna

Cepora perimale

Cepora perimale, Belenois java

Cepora perimale

Theclinesthes miskini

Nacaduba biocellata

Jamides phaseli

Lampides boeticus

Famegana alsulus

Candalides erinus

Candalides erinus

Delias argenthona, Candalides margarita, Ogyris amaryllis

Delias argenthona, Candalides margarita
Junonia orithya

\begin{abstract}
Acraea andromacha
\end{abstract}
Eurema hecabe

Eurema hecabe
Dry habitat 
in the tropical scrub of the Ord River.' The record was based on specimens labelled 'N.W. Australia' in the BMNH collected by A. Cunningham who visited both north-western Australia and Timor. Waterhouse (1932) and Common and Waterhouse (1972) subsequently followed Rothschild (1895) and attributed the record to a labelling error, noting that $P$. liris also occurs in Timor and its adjacent islands where several subspecies are recognised. Pachliopta liris is currently not officially recognised as being part of the Australian fauna, and since there is no additional evidence to indicate anything to the contrary, the species should remain excluded until proven otherwise.

\section{Telicota ancilla (Herrich-Schäffer, 1869)}

Evans (1949, p. 399) introduced the species group name baudina and described it as a subspecies of $T$. ancilla. He noted that T. ancilla baudina Evans, 1949, comprised 'A pale form with broad tawny areas and the dark border upf in $\hat{\sigma}$ traversed by tawny veins, resembling horisha and argilus. Unh as in argilus.' The taxon argilus referred to was a name introduced earlier by Waterhouse (1933) as a subspecies of Telicota augias (Linnaeus, 1763). Telicota augias argilus Waterhouse, 1933 (which was originally described as T. krefftii argilus) is now generally regarded as a junior synonym of $T$. augias krefftii (W.J. Macleay, 1866) (originally described as Pamphilla krefftii) due to the extent of variation on the underside of the hind wing (Braby 2000; 2010). Evans' (1949) concept of baudina was based on 16 syntypes $(15 \hat{\jmath}, 1$ q) in the BMNH, with specimens recorded from the north-western Kimberley at Queen Island (= Queen's Inlet, 1 $\delta^{\Uparrow}$ ) and Baudin Island $\left(9 \bigcirc^{\lambda}\right)$, Cassini Island $\left(1 \bigcirc^{\Uparrow}\right)$ and Parry Harbour $\left(1 \delta^{\Uparrow}\right)$ in the Admiralty Gulf, WA, and from Darwin $(3 \hat{\partial}, 1+)$ in the Top End, NT. Evans (1949, p. 399) gave the type locality as Baudin Island by stating that ' $\mathrm{O}$ Baudin Is.: J. J. Walker : type B.M.'; however, apart from placing a BMNH type label on one of the nine specimens from Baudin Island he did not designate a holotype. Edwards et al. (2001) referred to a holotype and gave type information, but this is interpreted as a lectotype designation (Article 74, ICZN 1999) since Evans did not explicitly state which specimen among the type series was the holotype. The lectotype male of Telicota ancilla baudina (Figures 12-14) is labelled as follows: 'Baudin I', 6/91, JJW', 'Walker coll, 91-155, Baudin I., vi.91.', 'Type | baudina Evans', 'BMNH(E) \#982813', genitalia mounted on separate card (BMNH). The label data thus indicates that the specimen was collected from the north-western Kimberley, WA, in June 1891 by J.J. Walker.

The only other species of Telicota that occurs in north-western Australia are T. augias krefftii and T. colon argea (Plötz, 1883) (Braby 2008). Telicota augias krefftii, which is restricted to northern Australia and the Torres Strait islands, occurs widely in the Kimberley and Top End where it breeds in patches of monsoon forest where the larval food plant Flagellaria indica L. (Flagellariaceae) grows, while $T$. colon argea is distributed similarly in north-western Australia but the larvae specialise on several grasses (Ischaemum australe Mnesithea rottboellioides,
Paspalum scrobiculatum) growing in non-rainforest habitats. Besides Evans' (1949) historical records of $T$. ancilla, there have been no subsequent reliable records of this species from north-western Australia. Although several authors have referred to material from the Top End (Hutchinson 1978; Dunn and Dunn 1991; Meyer et al. 2006) that they tentatively identified as a taxon (i.e. $T$. ancilla baudina) distinct from T. augias or T. colon, these records remain unconfirmed.

Examination and comparison of Evans' syntypes, including the lectotype male (Figures 12-14), in the BMNH with an extensive series of Telicota spp. from north-western Australia in the NTM, have confirmed that $T$. ancilla baudina is the same species as T. augias krefftii. The type locality of nominate $T$. augias augias is Java (Edwards et al. 2001). The type locality of $T$. augias krefftii is Cape York, QLD, while the type locality of T. augias argilus is Darwin, NT (Evans 1949; Edwards et al. 2001). The type specimens of these two species group names are illustrated in Figures 6-11 for comparison with the lectotype of T. ancilla baudina. Interestingly, in his description of argilus, Waterhouse (1933) referred to a specimen(s) from Baudin Island in the BMNH which he placed under that name, but not under T. ancilla. Evans (1949) only examined and compared three specimens of $T$. augias krefftii (under the name T. augias argilus) from north-western Australia $(2 \hat{\partial}, 19$ from Darwin) and he noted that this subspecies was distinguished in that it comprised 'A paler, yellower form...with broad tawny areas.' Although Evans did not explicitly say how baudina and argilus differed from each other, his description of the upperside of argilus differs little from baudina and, furthermore, he noted that the underside pattern of baudina was identical to that of argilus.

In Australia, T. augias males can be distinguished from those of $T$. ancilla by their smaller size, brighter and broader orange markings on the upperside, the less produced and more rounded tornus of the hind wing, and the lack of green suffusion to the underside ground colour; there are also pronounced differences in the genitalia (Braby 2000). In north-western Australia, $T$. augias and T. colon are sometimes difficult to distinguish, but in T. augias males the upperside ground colour is darker orange, the patch of androconial scales on the fore wing is darker grey, the orange ground colour distal to the postmedian band extends broadly along the veins but rarely reaches the termen, and the postmedian band on the upperside of the hind wing is usually broader. In T. augias, on the underside of the hind wing, the ground colour is darker orange with a broader postmedian band that is conspicuously edged with dark brown, whereas in T. colon the ground colour is yellow-orange often with a greenish tinge (more evident in reared specimens) and the postmedian band is narrower with the brown edge poorly developed or absent. In this regard, Evans' paralectotypes of baudina agree with $T$. augias than $T$. colon, although the lectotype male (Figures 12-13) is somewhat divergent from the rest of the type series.

The geographic distribution of T. ancilla in Australia 


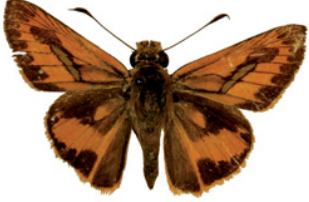

6

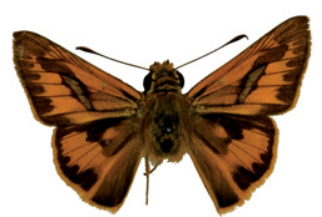

9

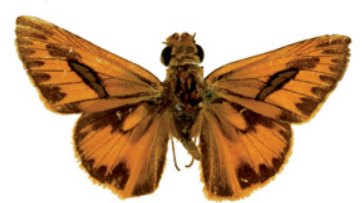

12

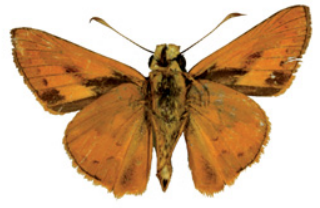

7

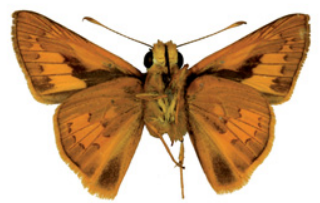

10

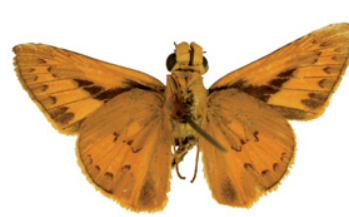

13

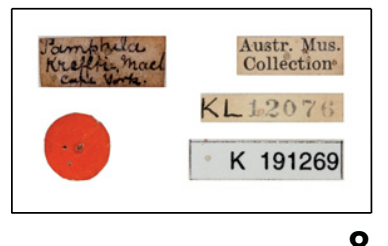

8

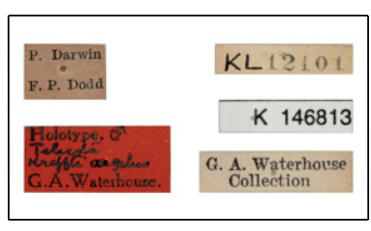

11

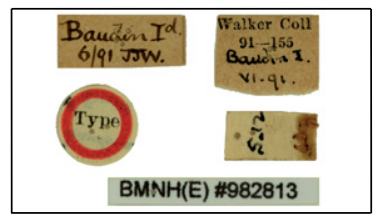

14

$20 \mathrm{~mm}$

FIGURES 6-14 Type specimens of Telicota augias from Australia: 6-8, lectotype male of Pamphila krefftii from Cape York, QLD (AM); 9-11, holotype male of Telicota krefftii argilus from Darwin, NT (AM); 12-14, lectotype male of Telicota ancilla baudina from Baudin Island, WA (BMNH). Shown for each type specimen is the upperside, underside and label data.

should now be excluded from the Kimberley and Top End, and revised to include only the eastern coast of Queensland and New South Wales. The synonymy of T. augias in Australia based on these nomenclatural changes is therefore as follows:

$$
\begin{aligned}
& \text { Telicota augias (Linnaeus, 1763) } \\
& \begin{array}{r}
\text { ssp. krefftii (W.J. Macleay, 1866) } \\
=\text { argilus Waterhouse, } 1933 \\
=\text { baudina Evans, } 1949
\end{array}
\end{aligned}
$$

\section{Pelopidas agna (Moore, [1866])}

Yeates (1990) recorded $P$. agna from the Kununurra district, WA, based on three males lodged in the WADA, and noted that one of the specimens had been reared from rice. Braby (2000, Plate 18, Figure 2) illustrated a specimen identified as $P$. agna from Kununurra (1우 labelled 'Kununurra, NT [sic], 2 Apr. 1970 emg, A.G. Wilson' ANIC), the specimen being part of a larger series that was identified and illustrated in the same publication as P. lyelli lyelli (Rothschild, 1915). Dunn and Dunn (1991) indicated that P. agna had been recorded from Derby, WA, as well as from several locations in the Top End of the Northern Territory, based on female specimens in the South Australian Museum which he tentatively assigned to this species. The three males in WADA referred to by Yeates (1990) are labelled as follows: $10^{\lambda}$ 'Kimberley Research Station, WA, Ex. Rice, 20.i.1963, K.T. Richards', 'DAFWA

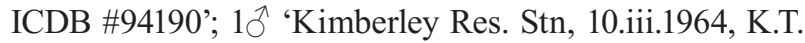

Richards', 'Pelopidas agna dingo Evans, Hesperidae, I.F.B. Common 1967', 'DAFWA ICDB \# 94191'; $1 \delta^{\lambda}$ 'Kununurra, WA, Ex. Farm, 7.i.1968, D. Hardie', 'DAFWA ICDB \#94192'. Examination of this material indicates that all specimens have been misidentified and are in fact $P$. lyelli. Examination of other material from the Kimberley and Top End preserved in the NTM indicates that all specimens belong to $P$. lyelli. Moreover, there are no known male specimens of $P$. agna from north-western Australia in any of the major museum collections in Australia (see also Dunn and Dunn 1991). Pelopidas lyelli males differ from those of $P$. agna principally by the relative position of the two white cell spots in relation to the patch of androconia on the upperside of the fore wing - a line drawn through these spots crosses the patch in $P$. lyelli but not in $P$. agna (Braby 2000). Females of the two species are more difficult to distinguish because the orientation of white cell spots on the fore wing varies in $P$. lyelli, but generally the spots are larger and more pronounced and the underside ground colour is paler compared with $P$. agna. The geographic distribution of P. agna in Australia should now be excluded from the Kimberley and Top End, and revised to include only the eastern coast of Queensland and northern New South Wales.

\section{Delias mysis (Fabricius, 1775)}

Records of D. mysis from the Kimberley were based on the observations of Warham (1957), who recorded the species from the western Kimberley at Derby, Cockatoo 
Island and Wotjalum Mission in Yampi Sound, WA. Subsequent authors (Common and Waterhouse 1972, 1981; Dunn and Dunn 1991; Hay et al. [1994]; Braby 2000) have attributed these records to the subspecies D. mysis aestiva Butler, 1897. The taxon aestiva, however, was considered by Braby (2012) to comprise a species distinct from $D$. mysis according to substantial comparative differences in morphology (male genitalia) and wing colour pattern of the adult, morphology and behaviour of the immature stages, and ecology. Warham (1957) did not retain voucher specimens, his records being based solely on observations, and his identifications were based on Waterhouse (1932), which neither provided illustrations nor distribution maps of D. aestiva Butler, 1897. Moreover, subsequent field studies by Koch and Van Ingen (1969) and McKenzie et al. (1995) at Koolan Island, which is adjacent to Cockatoo Island, did not list $D$. aestiva, but they did record $D$. argenthona fragalactea, a subspecies which occurs widely in coastal and savannah woodland areas of north-western Australia and which superficially resembles D. mysis mysis in that it has a relatively narrow scarlet subterminal band on the underside of the hind wing. Curiously, $D$. argenthona was not mentioned by Warham (1957) in his account of butterflies of the western Kimberley. Hence, it is very likely that Warham (1957) misidentified $D$. argenthona fragalactea as $D$. mysis, which has subsequently been interpreted to be $D$. aestiva. Hence, the geographic distribution of D. mysis in Australia should be revised to include only north-eastern Queensland, while that of $D$. aestiva be restricted to the Top End of the Northern Territory.

\section{Danaus plexippus (Linnaeus, 1758)}

Dunn (1980) observed an adult Danaus at Kununurra in late August 1979 when he was a Victorian high school student. He identified the specimen as D. plexippus and noted 'The adult flew past me near the main street in Kununurra opposite a large grassed area...probably a playing field I think. I recall chasing after it immediately with my net for about $100 \mathrm{~m}$ but it was going very fast and I could not catch up with it. I wanted the specimen for the record as I knew it was interesting. It flew at right angles to the main street and into the park. The adult was very old...much wing wear evident and quite faded. It was a large adult, and I saw the characteristic marking of plexippus.' (K.L. Dunn, pers. comm. 2011). Apart from this single record, D. plexippus otherwise is not known from north-western Australia, being more common in the subtropics of the south-east of the continent. The specimen in question may well have been confused with the similar looking D. genutia alexis (Waterhouse and Lyell, 1914), which occurs commonly in Kununurra where it breeds on the edge of Lily Creek Lagoon, banks of the lower Ord River and Lake Kununurra (Meyer 1995).

\section{Theclinesthes serpentatus (Herrich-Schäffer, 1869)}

Peters (2006, p. 114) recorded this species from the coastal town of Broome, WA, on 27 July 2001, noting that 'One male was collected in the grounds of the Mercure Inn'. The specimen was caught on a low flowering plant close to the reception office of the motel (J.V. Peters, pers. comm. 2011). Theclinesthes serpentatus otherwise is a species with a more temperate distribution and this record comprises the only known occurrence within the Kimberley and indeed the entire Australian monsoon tropics. Williams et al. (2006), however, recorded specimens from the same general locality, which they identified as T. sulpitius (Miskin, 1890), the sister species to T. serpentatus: three specimens were collected from a seasonal wetland area at Junction Pool, $9 \mathrm{~km} \mathrm{NNE}$ of Broome, WA, on 6 April 2003 by G. Swann (A.A.E. Williams pers. comm. 2011). I have examined and compared digital images of both adult collections from Broome and conclude that they belong to one and the same species, namely $T$. sulpitius. The specimens closely align with material I have collected from Wyndham, WA, and from near Darwin, NT. Both species closely resemble each other and are difficult to separate, but the main points of difference concern three colour pattern characters and one ecological character: (1) upperside ground colour; (2) extent of tornal spots on hindwing; (3) extent of white patch on underside of hindwing; and (4) habitat and larval food plant specialisation. In T. sulpitius, the upperside ground colour is brown with the blue area absent or restricted to the basal areas, whereas in $T$. serpentatus the blue area is extensive. The tornal spots on the hindwing in T. sulpitius are conspicuous, especially on the underside, whereas they are generally obscure in T. serpentatus. The white patch on the underside of the hindwing is usually present, but generally less extensive, in T. sulpitius, whereas it is always present and generally extensive in $T$. serpentatus. The larvae of T. sulpitius specialise on samphires in coastal mudflats, whereas $T$. serpentatus feed on a wide range of chenopod saltbushes other than samphires.

\section{ACKNOWLEDGEMENTS}

I thank Andy Williams and John Peters for comments on the manuscript, and for information and supplying digital images of Theclinesthes from Broome; David Lees for an extensive set of digital images of the type series of Telicota ancilla baudina in the BMNH, London; David Britton for providing digital images of the type specimens of Telicota augias krefftii and Telicota augias argilus in the AM, Sydney; Andras Szito for digital images of Pelopidas material preserved in WADA, Perth; and Kelvyn Dunn for historical information of Danaus. I am particularly grateful to Sean Doody for critically reading the manuscript and his leadership during the AGS survey in 2011, Micko Bass (Park Manager of El Questro Wilderness Park) for providing permission to undertake fieldwork, the Australian Geographic Society for financial support during the field expedition in 2011, and the numerous volunteers (B. Clarkson, S. Fallon, J. Fenwick, B. Hanekom, B. Jacobs, B. Mactaggart, S. Maynard, E. Munnings, G. Parker, T. Schwinghammer, L. Vanderwyk, C. Walsh, W. Wiegand, E. Wiegand and S. Wren) who assisted with fieldwork and recording butterflies at ElQ.

\section{REFERENCES}

Bailey, W.J. and Richards, K.T. (1975). A report on the insect fauna of the Prince Regent River Reserve, north-west 
Kimberley, Western Australia. In: Miles, J.M. and Burbidge, A.A. (eds) A Biological Survey of the Prince Regent River Reserve, North-West Kimberley, Western Australia, in August, 1974. Pp 101-112. Department of Fisheries and Wildlife: Perth.

Bowman, D.M.J.S., Brown, G., Braby, M.F., Brown, J., Cook, L., Crisp, M.D., Ford, F., Haberle, S., Hughes, J.M., Isagi, Y., Joseph, L., McBride, J., Nelson, G. and Ladiges, P.Y (2010). Biogeography of the monsoon tropics. Journal of Biogeography 37: 201-216.

Braby, M.F. (2000). Butterflies of Australia. Their Identification, Biology and Distribution. CSIRO Publishing: Collingwood, Melbourne.

Braby, M.F. (2008). Biogeography of butterflies in the Australian monsoon tropics. Australian Journal of Zoology 56: 41-56.

Braby, M.F. (2010). The merging of taxonomy and conservation biology: a synthesis of Australian butterfly systematics (Lepidoptera: Hesperioidea and Papilionoidea) for the 21st century. Zootaxa 2707: 1-76.

Braby, M.F. (2011). New larval food plant associations for some butterflies and diurnal moths (Lepidoptera) from the Northern Territory and eastern Kimberley, Australia. The Beagle, Records of the Museums and Art Galleries of the Northern Territory 27: 85-105.

Braby, M.F. (2012). The taxonomy and ecology of Delias aestiva Butler, 1897 stat. rev. (Lepidoptera: Pieridae), a unique mangrove specialist of Euphorbiaceae. Biological Journal of the Linnean Society 107: 697-720.

Bureau of Meteorology (2012). Climate data online. http://www. bom.gov.au/climate/data/. Accessed 22 May 2012.

Common, I.F.B. (1981). Part IV. Insects. In: McKenzie, N.L. (ed) Wildlife of the Edgar Ranges area, south-west Kimberley, Western Australia. Wildlife Research Bulletin of Western Australia. No. 10. Pp 60-67. Department of Fisheries and Wildlife: Perth.

Common, I.F.B. and Waterhouse, D.F. (1972). Butterflies of Australia. Angus and Robertson: Sydney.

Common, I.F.B. and Waterhouse, D.F. (1981). Butterflies of Australia. Revised edition. Angus and Robertson: Sydney.

Dunn, K.L. (1980). A Northern Territory-Western Australia safari. Victorian Entomologist 10: 4-6.

Dunn, K.L. (1985). Specimens of interest in the J.C. Le Souef collection of Australian butterflies. The Victorian Naturalist 102: 94-98.

Dunn, K.L. and Dunn, L.E. (1991). Review of Australian butterflies: Distribution, Life history and Taxonomy. Parts 1-4. Privately published by the authors: Melbourne.

d'Apice, J.W.C. and Miller, C.G. (1992). The genus Nesolycaena Waterhouse and Turner (Lepidoptera: Lycaenidae) with a description of a new species. Australian Entomological Magazine 19: 75-80.

Edwards, E.D., Newland, J. and Regan, L. (2001). Lepidoptera: Hesperioidea, Papilionoidea. Zoological Catalogue of Australia. Vol. 31.6. CSIRO Publishing: Collingwood, Melbourne.

Evans, W.H. (1949). A catalogue of the Hesperiidae from Europe, Asia, and Australia in the British Museum (Natural History). British Museum (Natural History): London.

Field, R.P. (1990). Range extensions and the biology of some Western Australian butterflies. Victorian Entomologist 20: $76-82$.

Franklin, D.C., Michael, B. and Mace, M. (2005). New location records for some butterflies of the Top End and Kimberley regions. Northern Territory Naturalist 18: 1-7.

Grund, R. (1998). New foodplant recordings and biological observations for some Western Australian butterflies. Victorian Entomologist 28: 65-68.

Grund, R. and Hunt, L. (2001). Some butterfly observations for the Kimberley and Tanami regions, Western Australia. Victorian Entomologist 31: 19-23.

Hay, R.W., Houston, T.F., Williams, A.A.E. and Williams, M.R.
[1994]. Bring Back the Butterflies. Butterfly Gardening for Western Australians. Western Australian Museum: Perth.

Hutchinson, J.F. (1978). Butterflies of the Daly River area, Northern Territory. Victorian Entomologist 8: 15-19.

ICZN (1999). International Code of Zoological Nomenclature. International Trust for Zoological Nomenclature: London.

Johnson, S.J. (1993). Butterfly records of interest from northern Australia. The Australian Entomologist 20: 75-76.

Koch, L.E. (1957). East Kimberley butterflies. Western Australian Naturalist 11: 83-84.

Koch, L.E. and van Ingen, F.C. (1969). The butterflies of Koolan Island, Western Australia. Western Australian Naturalist 11: 98.

Le Souëf, J.C. (1971). Winter insect collecting in the Northern Territory. The Victorian Naturalist 88: 350-356.

McKenzie, N.L., Fontanini, L., Lindus, N.V. and Williams, M.R. (1995). Biological inventory of Koolan Island, Western Australia 2. Zoological notes. Records of the Australian Museum 17: 249-266.

Meyer, C.E. (1995). Notes on the life history of Danaus genutia alexis (Waterhouse and Lyell) (Lepidoptera: Nymphalidae: Danainae). The Australian Entomologist 22: 137-139.

Meyer, C.E. (1996a). Butterfly larval food plant list for the Northern Territory and the Kununurra District in Western Australia. Victorian Entomologist 26: 66-72.

Meyer, C.E. (1996b). A new record of Nesolycaena caesia d'Apice \& Miller (Lepidoptera: Lycaenidae) from north-eastern Western Australia. The Australian Entomologist 23: 79.

Meyer, C.E., Weir, R.P. and Wilson, D.N. (2006). Butterfly (Lepidoptera) records from the Darwin region, Northern Territory. The Australian Entomologist 33: 9-22.

Peters, J.V. (2006). New distribution records for Australian butterflies (Lepidoptera). The Australian Entomologist 33: $113-114$.

Peters, J.V. (2008). New distribution records for Australian butterflies (Lepidoptera: Lycaenidae) from Broome, Western Australia. The Australian Entomologist 35: 66.

Pierce, F. (2008). Range extension records for various butterflies throughout Australia. Victorian Entomologist 38: 15-16.

Pierce, F. (2010). More range extension records for various butterflies throughout Australia. Victorian Entomologist 40: 133-134.

Rothschild, L.W. (1895). A revision of the papilios of the Eastern Hemisphere, exclusive of Africa. Novitates Zoologicae 2: 167-463.

Warham, J. (1957). West Kimberley butterflies. Western Australian Naturalist 5: 229-230.

Waterhouse, G.A. (1932). What Butterfly is That? Angus and Robertson: Sydney.

Waterhouse, G.A. (1933). Australian Hesperiidae. IV. Notes and descriptions of new forms. Proceedings of the Linnean Society of New South Wales 58: 461-466.

Waterhouse, G.A. and Lyell, G. (1914). The Butterflies of Australia. A monograph of the Australian Rhopalocera. Angus and Robertson: Sydney.

Williams, A.A.E., Williams, M.R. and Swann, G. (2006). Records of butterflies (Lepidoptera) from the Kimberley region of Western Australia. Victorian Entomologist 36: 9-16.

Woinarski, J.C.Z., Mackey, B.G., Nix, H.A. and Traill, B. (2007). The Nature of Northern Australia. Natural Values, Ecological Processes and Future Prospects. ANU E Press: Canberra.

Yeates, D.K. (1990). New records of butterflies from the east Kimberley, Western Australia. Australian Entomological Magazine 17: 73-74.

MANUSCRIPT RECEIVED 22 MAY 2012; ACCEPTED 11 OCTOBER 2012. 